\title{
Household labor supply and intermarriage of immigrants: differences by gender
}

Sukanya Basu

Correspondence: subasu@vassar.edu Department of Economics, Vassar College, 124 Raymond Avenue, 12604 Poughkeepsie, NY, USA

\begin{abstract}
Intermarriage between a native and immigrant can affect the household's supply of labor hours. Spouse selectivity on the basis of human capital, distribution of bargaining power, and labor supply coordination within the household can differ by type of marriage and gender of the immigrant-and, consequently, affect how spouses supply labor to the market. Using the 2010 American Community Survey, a household labor market specialization index is created. Raw two-limit Tobit estimates show lower specialization in intermarried households for both genders, compared to their intra-married counterparts. The finding for intermarried female households is reversed, and gender-based specialization increases, when controls for human capital are introduced. The role of immigrant education for both intermarried men and women is underscored - specialization differences, by type of marriage, are insignificant when the immigrant has post-college education. At lower levels of immigrant education, native spouses supply more market labor. Intermarriage may also skew bargaining power in favor of native husbands in immigrant female households.
\end{abstract}

JEL Classifications: J1, J16, J12, J22

Keywords: Household labor supply, Gender, Immigrants, Intermarriage

\section{Introduction}

Intermarriage between minority and majority groups is often considered the "final stage" in assimilation for ethnic minorities (Gordon 1994). The common perception is that intermarriage among immigrants and natives "closes the socioeconomic gap" between these groups. ${ }^{1}$ A surge in the foreign-born population in recent decades has made it easier for immigrants to marry within one's nativity. As a result, the proportion of intermarriages among the dominant ethnic groups is declining (Basu 2015; Lichter et al. 2011). ${ }^{2}$ The role of natives in the household formation and, consequently, the labor market outcomes of immigrants is debated in the USA and often contrasted with other developed countries.

Immigrants in Europe and Australia, particularly men, receive income benefits from intermarriage via access to better social networks and increased labor market integration (Meng and Gregory 2005; Meng and Meurs 2006; Nottmeyer 2015). On the other hand, the intermarriage wage premium for immigrant males in the USA is small and can be explained by positive selection into marriage and the labor market (Kantarevic 2004; Chi 2015). ${ }^{3}$ Immigrant women in the USA receive an intermarriage wage penalty

(c) The Author(s). 2017 Open Access This article is distributed under the terms of the Creative Commons Attribution 4.0 International License (http://creativecommons.org/licenses/by/4.0/), which permits unrestricted use, distribution, and reproduction in any medium, provided you give appropriate credit to the original author(s) and the source, provide a link to the Creative Commons license, and indicate if changes were made. 
which is explained via a combination of unobservable heterogeneity, spousal income effects, and labor market prospects forgone for "home-building" (Basu 2015).

The lack of a wage premium for intermarried immigrants in the USA can be considered in the light of household labor market specialization. Intermarriage is seen to reduce labor force participation for men and significantly more for women (Basu 2016). Clearly, the type of marriage affects an immigrant's participation decision, and this effect differs by immigrant gender. However, marriage is fundamentally a matching decision between partners, and the type of marriage may not just affect individual decisions but also the household market specialization decision. In other words, the type of marriage can affect the relative supply of labor by spouses. If type of marriage affects which spouse in the household supplies labor primarily, and to what extent, this could help explain the income and employment outcomes seen for intermarried immigrants in the US labor market. Also, labor market returns of intermarried male and female immigrants are different (Basu 2015). Again, the differences in household specialization, not only by type of marriage but also by gender of the immigrant, could further our understanding of the links between socioeconomic and cultural assimilation of immigrants.

Intermarriages are characterized by positive assortative mating on human capital (Chiswick and Houseworth 2011; Furtado 2012). Similar education attainment can lead intermarried couples to supply similar levels of labor market hours and, hence, exhibit lower household specialization compared to intra-married couples. The process of immigration and intermarriage can weaken traditional gender-based male-breadwinnerfemale-homemaker specialization models (Espiritu 1999). However, Jasso et al. (2000) show that spouse selectivity, based on human capital, differs for intermarried men and women. Therefore, division of labor in the household can differ by sex of the intermarried immigrant spouse. Status exchange theory theorizes that immigrants may give up their career aspirations in exchange for higher status from marriage to a native, and this is truer for immigrant women (Grossbard-Shechtman 1993; Grossbard-Shechtman and $\mathrm{Fu}$ 2002). Bargaining power in intermarried households can weigh heavily towards natives due to their greater familiarity with host-country conditions. Gender-based divisions of labor can be reinforced in intermarriages for female immigrants.

Using data from the 2010 American Community Survey (ACS), this paper estimates the impact of intermarriage on household labor market specialization of married immigrants. The analysis is conducted separately for male and female immigrants. The comparison group is intra-married immigrant families. A married couple jointly decides on the optimal allocation of their market hours based on their relative productivities and other costs and benefits. They can decide to supply equal number of hours-this is the case of no labor market specialization. Or only one spouse can choose to participate in the labor market-this is the case of complete specialization. Thus, this paper does not model an immigrant's labor supply decision (Basu 2016) but the household's. To deal with corner solutions of no and complete specialization, we use a two-limit Tobit specification. Immigrant and spousal observable characteristics and characteristics of the marriage are included to account for the couple's observable selection into marriage type and market labor. Birthplace controls are introduced in certain specifications.

The raw estimates show a lower degree of specialization in intermarried households vis-à-vis intra-married couples, irrespective of the gender of the immigrant. This finding is reversed for intermarried female households ${ }^{4}$-immigrant wife and native 
husband families-when controls for human capital are introduced. These households exhibit more gender-based specialization. Intermarried male households-immigrant husband and native wife families-still exhibit less specialization, though the gap vis-àvis intra-married households is smaller. Marriage characteristics and birthplace controls, while important, do not change this result.

Previous researchers state the need to control for unobservable selection into marriage and endogeneity of the marriage and work decisions (Meng and Gregory 2005; Kantarevic 2004). We use an alternate instrumental variable (IV) specification, using an instrument for own-country group size, which measures the availability of mates from one's own country relative to natives, in the immigrant's residential area. There are concerns about the instrument, and the paper primarily focuses on the two-limit Tobit estimates, though the IV results support our main findings.

The paper analyzes the sources of differences in household specialization by type of marriage and immigrant gender. Immigrant education is an important determinant of household specialization. There is no significant difference among intermarried and intra-married households, when the immigrant has post-college education. This is true for both genders. For lower levels of education, intermarried male households have a lower level of specialization compared to intra-married families. The opposite is true for intermarried female households at the lower end of the education distribution. We consider this as evidence of native spouses supplying more labor to compensate for their immigrant spouse's lack of human capital.

To look at the role of bargaining power in the household, we compare intermarried couples to cohabiting couples where at least one member is an immigrant. Stratton (2005) posits that bargaining power is more evenly divided among cohabiting couples, over married couples, due to the shorter duration of cohabitations. Cohabitation with a native, instead of another immigrant, significantly reduces specialization in female immigrant households. Legal marriage to a native husband may skew bargaining away from the immigrant wife and reinforce gender-based specialization, which is less true of cohabitations.

The paper is organized as follows. Section 2 provides the theoretical background and introduces the empirical specification. Section 3 discusses the data and sample selection. Section 4 shows estimation results, and Section 5 discusses possible explanations for the findings. Section 6 provides robustness checks, where we alter our sample selection criterion. Section 7 concludes.

\section{Theoretical background}

\subsection{Previous literature}

Previous theories on the determinants of intermarriage also have implicit predictions about relative market labor supply by spouses. Intermarriages exhibit positive assortative mating among spouses-natives and immigrants with similar level characteristics tend to intermarry. This is particularly true of individuals with higher levels of education and proficiency in the English language (Chiswick and Houseworth 2011; Furtado 2012). Immigrants who arrive in the USA at an early age and have a similar experience of US life as natives have a higher propensity to intermarry. Nottmeyer (2014) also shows that intermarried immigrants score high on the personality traits of "openness" 
and "extraversion." Immigrants and natives who intermarry may be less inclined to follow gender-based household division of labor.

Becker's work on family division of labor $(1981 ; 1985)$ posits that husbands and wives choose to specialize in market versus house work based on their productivities and abilities. Couples choose the degree of specialization based on the expected costs and benefits (Stratton 2005). Married households can allocate spousal hours more efficiently, compared to single people, to maximize home production and work income (Lundberg and Pollak 2007). The natural assumption is that a partnership decision like marriage will affect not only how individuals decide to supply labor but also how spouses jointly decide on their market labor supply.

A couple that is similarly matched on human capital variables like education or language proficiency is unlikely to have differing comparative advantages. Benefits from specialization are limited. Intermarriages, where partners have more equal endowments of human capital, may be characterized by more equal division of labor market work. However, it is not clear that this "equality" is true for both male and female intermarriages. The average levels of education can differ by sex of the native partner (Jasso et al. 2000). For example, in the USA, native husbands and their wives have substantially more schooling than native wives and their husbands. This can affect traditional gender-based division of market labor heterogeneously by sex of the immigrant. Also, couples may not always match on human capital traits-for example, if natives marry immigrant women from traditional societies to reemphasize home-building and childrearing (Basu 2015), household specialization might be efficient in certain intermarried female families. Educated immigrants, particularly women, may exchange their labor market aspirations for higher societal status from marriage to a native (GrossbardShechtman 1993) - this is a special case of status exchange.

The productivity hypothesis of intermarriage states that immigrants marry natives to compensate for their lack of host-country-specific human capital. ${ }^{5}$ Intermarriage can encourage an immigrant to acquire more human capital, via added incentives in learning the language and culture of the home country as well as attachment to the labor market (Meng and Gregory 2005). ${ }^{6}$ English proficiency or extended stay in the USA is not merely determinants of intermarriage; rather, intermarriage affects these variables and via these channels can affect household specialization. We recognize that these immigrant characteristics can change over the course of the marriage. Given their importance in determining type of marriage and labor market hours, we retain them as controls in our subsequent estimations.

A native spouse can also reduce information costs surrounding local job markets and institutions and increase employment opportunities (Furtado and Theodoropoulos 2010). Factors that improve an immigrant's labor market options can imply similar work hours as their native spouse and thereby lower household specialization.

In certain cases, acquisition of human capital over the course of a marriage might occur in intra-marriages. Labor market effort and human capital investment can be better coordinated among intra-married couples and not intermarried couples. Baker and Benjamin (1997) show for Canada, upon arrival, intra-married immigrant women work in low-paying, high-hour jobs to finance their husband's human capital investment in a credit-constrained labor market. Eventually, both husbands and wives move to better jobs. This is the family investment hypothesis in intra-marriages (Eckstein and Weiss 
2002). Intermarried wives do not have to perform this borrowing function for native husbands. ${ }^{7}$ Intermarriages are also characterized by high family incomes (Pew Research Center 2012). The income effect of a high-earning native husband can reduce a wife's labor supply (Basu 2015).

The above discussion indicates that own and relative (to spouse) human capital-like education and age-are important determinants of intermarriage and household market specialization. The discussion also indicates that the variables do not affect male and female immigrants similarly, and hence, effects of intermarriage on household labor supply should be considered separately for male and female immigrants.

Besides human capital, the distribution of bargaining power can differ between intermarriages and intra-marriages. Cross-racial and cross-nativity marriages are more likely to end in divorce (Milewski and Kulu 2014; Adserà and Ferrer 2014). If options outside the marriage are more attractive, and the threat of divorce is greater, gender-based division of labor is less optimal in the marriage (Becker 1985). Specialization is attractive when a marriage is expected to continue. More children increase the opportunity cost of market hours particularly for the primary-care giver, often the mother. Intermarried households have lower fertility rates and are less stable than immigrant households. Overall, intermarriages should be characterized by less specialization than intramarried households, though clearly the sex of the intermarried immigrant matters. Also based on this discussion, characteristics of the marriage like duration of the marriage, number of children, and presence of young children are important determinants of household specialization.

On the other hand, cohabiting with a native, with or without marriage, can tilt bargaining power away from an immigrant. Marriages are costly to dissolve, compared to cohabitations (Stratton 2005). Household bargaining models posit that the partner with the more attractive outside options can dictate household allocation of hours (Lundberg and Pollak 1996). ${ }^{8}$ In any form of native-immigrant partnerships, this is presumably the native partner. In legal marriages particularly, the immigrant can depend on the native spouse for legal residence in the USA. This paper also examines unmarried cohabiting native-immigrant couples to identify the sources of bargaining power-the act of marriage over and above cohabitation with a native.

A higher sex ratio, defined as the proportion of immigrant women to men available in one's marriage market, increases the rate of intra-marriage for men and lowers it for women. Regional sex ratios are also inversely related to married women's labor force participation in the USA (Grossbard and Amuedo-Dorantes 2008). Clearly, these variables affect the household specialization of married couples, and the effects differ by sex of the immigrant. Our regressions control for state of residence and regional female-male sex ratio. Also included is the proportion of immigrants from one's birthplace that lives in one's metropolitan-this variable seeks to measure the segregation of immigrants.

An immigrant's place of birth influences their labor market participation (Basu 2016). ${ }^{9}$ Culture has an important impact (Gevrek et al. 2013), and immigrant women from countries with higher female labor participation exhibit the same in the host country. Source-country differences play an important role in immigrant labor supply and therefore household specialization.

Previous studies relating intermarriage to labor market outcomes of immigrants have concentrated on immigrant wages or employment. Intermarriage can affect how a 
couple allocates their labor market hours. Nottmeyer (2014) finds that intermarriages in Germany are characterized by lower labor market specialization for both men and women. Conducting a similar exercise for immigrants in the USA would present a clearer picture of immigrant income assimilation. A study of the sources of gender differences in household specialization can contribute to our understanding of the US gender wage gap, as more immigrants enter the labor force.

\subsection{Variable construction and empirical specification}

The variable of interest $S_{i h}$, or the dependent variable, is the degree of specialization in labor market hours in household $h$. The index is constructed from the point of view of immigrant $i$. Following previous work (Stratton 2005; Bonke et al. 2008; Nottmeyer 2014), this is defined as:

$$
S_{i h}=\left(\frac{\max \left\{H_{i, h} ; H_{j, h}\right\}}{H_{i, h}+H_{j, h}}-0.5\right) * 2
$$

where $H_{i, h}$ and $H_{j, h}=$ usual weekly market hours supplied by immigrant $i$ and spouse $j$, respectively. Spouse $j$ can be a native or another immigrant. It bears clarification that while the index carries the subscript $i$, it is common for spouses $i$ and $j . S_{i h}$ is a degree of specialization chosen by the household $h$ based on the abilities of the spouses. Subscript $i$ helps to differentiate between spouses, since individual and relative characteristics will be included in the estimation. ${ }^{10}$

The value of this measure ranges from 0 , where hours supplied by both spouses is the same. This is the case of no specialization in labor market work. The other extreme is complete specialization in labor market work by one spouse, while the partner stays out of the labor market entirely. Here, the index takes a value of 1 . The index allows for a continuum of incomplete but increasing specialization between the values of 0 and 1 .

This index is gender-neutral. In our sample, which we discuss in the next section, households generally follow the traditional model of male-breadwinner-female-homemaker. Thus, despite its gender-neutrality, if household $h$ has a higher value of the specialization index than household $h^{\prime}$, it is likely that household $h$ follows more traditional gender roles. A concern with this index is that it uses aggregate weekly labor market hours worked by individuals-this is a facet of the data. A person who works more during the weekdays may trade off with their spouse over the weekends-thereby pointing at specialization-but in aggregate, this might not be visible.

By construction, the index is bounded between 0 and 1. It has positive mass at these limits. The two-limit Tobit estimation is used to model corner solutions. This is a special case of the censored regression model, where the dependent variable is simultaneously censored from above and below. The model supposes there is a latent unobserved variable $S_{i h}^{*}=\beta$ Inter $_{i h}+\gamma X_{i h}+\varepsilon_{i h}$, with $\varepsilon_{i h}$ as a normally distributed error term $\sim N(0, \sigma)$. The observed specialization $S_{i h}$ equals latent variable $S_{i h}^{*}$ when it lies between 0 and 1 . Spouses solve their labor market hour allocation comparing the costs and benefits from different degrees of specialization. The result of this optimization exercise is $S_{i h}$.

The latent variable linearly depends on the vector of observed explanatory variables via the coefficient parameter. The important explanatory variable is Inter $_{i h}$ which equals 0 if both spouses are immigrant and 1 if exactly one spouse is a native. ${ }^{11}$ The 
coefficient of interest is $\beta$. Estimations are conduced separately for married male and female immigrants, and we obtain different values of $\beta$ depending on gender. The coefficient $\beta$ shows the average difference in observed specialization between intermarried and intra-married immigrants, for a given gender.

Based on our discussion of intermarriages and specialization in these marriages, other controls included in vector $X_{i h}$ are the following: education of spouse $i$, a square term in experience for $i$, more years of education and age for $i$ compared to spouse $j,{ }^{12}$ years spent in the USA by immigrant $i$, and their English language proficiency. Veteran status of both spouses are also included. In addition, marriage characteristics-like age of marriage of $i$, duration of marriage, family size, number of children, and age of the youngest child in the household-are also included. Additionally, we include a sex ratio variable estimating the proportion of women to men for $i$ 's age group, country of birth, and metropolitan statistical area (MSA). A control for immigrant concentration is also included-which specifies the proportion of own-country immigrants living in one's MSA. ${ }^{13}$ Birthplace controls and state fixed effects are included in some specifications.

The coefficients from a Tobit estimation are interpreted similar to ordinary-least-square coefficients. The linear effects are on the uncensored latent variable, not the observed outcome. Marginal effects, assuming the specialization index is greater than 0 (excluding cases of no specialization), or less than 1 (excluding cases of complete specialization) or where the specialization index lies between 0 and 1 (incomplete specialization), are available upon request. While the magnitudes of these effects are different from the results presented in subsequent tables, qualitative results were the same.

\section{Data}

\subsection{Sample selection}

Our analysis uses the 2010 American Community Survey (ACS), particularly the Integrated Public Use Microdata Series (IPUMS) (Ruggles et al. 2013). The ACS is an annual statistical survey conducted by the US Census Bureau, and the 2010 ACS is a $1 \%$ random sample of the US population. The survey asks respondents questions previously seen on the long form of the decennial census. The ACS includes a large number of immigrant households and has rich information of the immigrants' demographic and human capital characteristics like education, age, and labor market hours.

Husbands and wives can be matched to each other if they live in the same household. ${ }^{14}$ We are interested in the impact of intermarriage vis-à-vis intra-marriage of immigrants on labor market specialization and not an impact of marriage per se. Our sample is restricted to heterosexual married immigrants, and their spouse may be another immigrant or a native. The 2010 ACS reports immigrants' year of arrival, year of marriage, and the incidence of marriage. Structural factors influencing marriage and labor market choices differ across countries. To ensure that the marriage decision was taken in the USA, we restrict the data to immigrants who married after their arrival to the USA and are currently in their first marriage. Collinearity with other age and duration variables precludes us from adding age of arrival to the USA as a control.

Cross-nativity and cross-racial marriages are more likely to end in divorce. Intact marriages, and marriages that are expected to endure, usually involve more specialization. Since we focus on marriages that are continuing, we may have selected 
marriages where the division of labor is better established and higher than all marriages on average.

Only families where both spouses are between 22 and 64 years of age are included. The age restriction assumes people have finished school and are of labor market age. ${ }^{15}$ We do not exclude people still in school but include a binary indicator for enrollment. Individuals born abroad to US parents are excluded, since citizenship rules for them have changed over time.

\subsection{Descriptive statistics}

Table 1 compares characteristics of intermarried and intra-married male and female immigrants and their marriages. About $24 \%$ of the immigrant men and $28 \%$ of the immigrant women in the sample have native spouses. Consistent with positive selection into intermarriage and the labor market (Meng and Gregory 2005; Nottmeyer 2015), average human capital of intermarried immigrants is higher. Intermarried immigrants, and their native spouses, have more years of education. Characteristics like years of stay in the USA and English proficiency ${ }^{16}$, which are correlated with investment in hostcountry skills, are "better" on average for intermarried individuals contrasted with intra-married immigrants. Marriage characteristics, like age at marriage and duration of marriage, are comparable across intermarried and intra-married households.

There are further differences in immigrant labor market hours by gender of the immigrant-intermarried men and women work more average labor market hours (41 and $28 \mathrm{~h}$ per week, respectively) than their intra-married counterparts (40 and $25 \mathrm{~h}$ weekly, respectively). Also worth noting is that native spouses work more market hours than immigrant spouses.

In order to understand household specialization, a measure of relative hours worked by spouses presents a clearer picture compared to descriptive statistics. Figure 1 shows the level of specialization $\left(S_{i h}\right)$ by type of marriage and gender of the immigrant. It is worth noting that incomplete labor market specialization-where both spouses work-is common in intermarried households (nearly 50\%). Complete specialization, where only one spouse works, occurs more in intra-married households (40 versus $30 \%$ of intermarried households). Figure 1 also shows that only 5-6\% of households exhibit complete specialization with the woman providing all the labor market hours. ${ }^{17}$ Hence, households mostly follow the traditional male-breadwinner-female-homemaker models. Even though $S_{i h}$ is created to be gender-neutral, an increase in value is usually associated with husbands working relatively more market hours.

\section{Estimation results}

\subsection{Two-limit Tobit estimates}

Given the likelihood of corner solutions (no or complete specialization), we use a twolimit Tobit specification to estimate the difference in household labor market specialization between intermarried and intra-married immigrant families. Table 2 presents these estimation results.

The raw estimates in columns 1 and 2 show that intermarried households are less specialized compared to intra-married households, irrespective of gender of the married immigrant. Intermarriage decreases specialization by about $22 \%$ in immigrant male 
Table 1 Descriptive statistics of married immigrants: by type of marriage

\begin{tabular}{|c|c|c|c|c|}
\hline & \multicolumn{2}{|c|}{ Married male immigrants } & \multicolumn{2}{|c|}{ Married female immigrants } \\
\hline & Immigrant wife & Native wife & Immigrant husband & Native husband \\
\hline Percentage & 75.68 & 24.32 & 72.31 & 27.69 \\
\hline \multirow[t]{2}{*}{ Weekly market hours } & 39.79 & 41.02 & 25.15 & 27.94 \\
\hline & (13.78) & (15.13) & $(19.42)$ & $(19.06)$ \\
\hline \multirow[t]{2}{*}{ Years of education } & 12.3 & 13.69 & 12.31 & 14.68 \\
\hline & $(4.86)$ & (3.95) & $(4.46)$ & $(3.15)$ \\
\hline \multirow[t]{2}{*}{ Age } & 42.46 & 41.73 & 40.5 & 40.64 \\
\hline & $(9.65)$ & $(10.72)$ & $(9.77)$ & $(10.53)$ \\
\hline \multirow[t]{2}{*}{$\%$ with good English } & 46.99 & 79.72 & 47.19 & 86.08 \\
\hline & (49.99) & $(40.21)$ & $(49.92)$ & $(34.62)$ \\
\hline \multirow[t]{2}{*}{ Years in USA } & 23.09 & 27.97 & 22.6 & 27.52 \\
\hline & $(10.44)$ & (13.88) & $(10.96)$ & $(13.62)$ \\
\hline \multirow[t]{2}{*}{ Lives in a metro } & 93.73 & 89.33 & 94.18 & 91.09 \\
\hline & $(24.24)$ & (30.88) & $(23.42)$ & $(28.49)$ \\
\hline \multirow[t]{2}{*}{ In school } & 4.15 & 5.77 & 6.26 & 9.07 \\
\hline & $(19.95)$ & $(23.31)$ & $(24.23)$ & $(28.72)$ \\
\hline \multicolumn{5}{|c|}{ Marriage and spouse characteristics } \\
\hline \multirow[t]{2}{*}{ Age of marriage } & 27.42 & 27.07 & 26.28 & 26.17 \\
\hline & $(6.24)$ & $(5.65)$ & $(6.28)$ & $(5.62)$ \\
\hline \multirow[t]{2}{*}{ Marriage duration } & 14.04 & 14.66 & 14.23 & 14.47 \\
\hline & $(9.44)$ & $(11.03)$ & $(9.92)$ & $(11.09)$ \\
\hline \multirow[t]{2}{*}{ No. of children } & 1.77 & 1.5 & 1.74 & 1.33 \\
\hline & $(1.26)$ & $(1.26)$ & $(1.26)$ & $(1.19)$ \\
\hline \multirow[t]{2}{*}{ Spouse market hours } & 23.13 & 27.61 & 39.03 & 41.18 \\
\hline & $(19.73)$ & $(18.61)$ & $(14.36)$ & $(14.88)$ \\
\hline \multirow[t]{2}{*}{ Spouse education } & 12.29 & 14.39 & 12.26 & 14.94 \\
\hline & $(4.61)$ & $(2.92)$ & $(4.73)$ & (3.13) \\
\hline \multirow[t]{2}{*}{ Spouse age } & 39.49 & 39.41 & 42.76 & 42.42 \\
\hline & $(9.65)$ & $(10.12)$ & $(10.21)$ & $(10.82)$ \\
\hline$N$ & 25,637 & 8238 & 19,462 & 7451 \\
\hline
\end{tabular}

Source: 2010 ACS. Appropriate person weights used in the calculations

households and $12 \%$ in immigrant female households. Increased specialization usually involves husbands working more hours than wives-hence, the raw estimates point to a weakening of the traditional gender work norms. Positive coefficients on variables similarly indicate a strengthening of gender norms.

Columns 3 and 4 introduce the immigrant's own human capital characteristics and also include controls for increases in education and age with respect to the spouse. Decreased specialization continues for intermarried male households, compared to their intra-married counterparts, albeit the coefficient points to a smaller magnitude. The finding is reversed for women. Households with immigrant wives and native husbands are $10 \%$ more likely to be specialized compared to intra-married households. Therefore, the lower specialization in intermarried female households seen in column 2 stem from better observable human capital, which contribute to better labor market prospects for women and lower household specialization. Host-country-specific human capital-like 


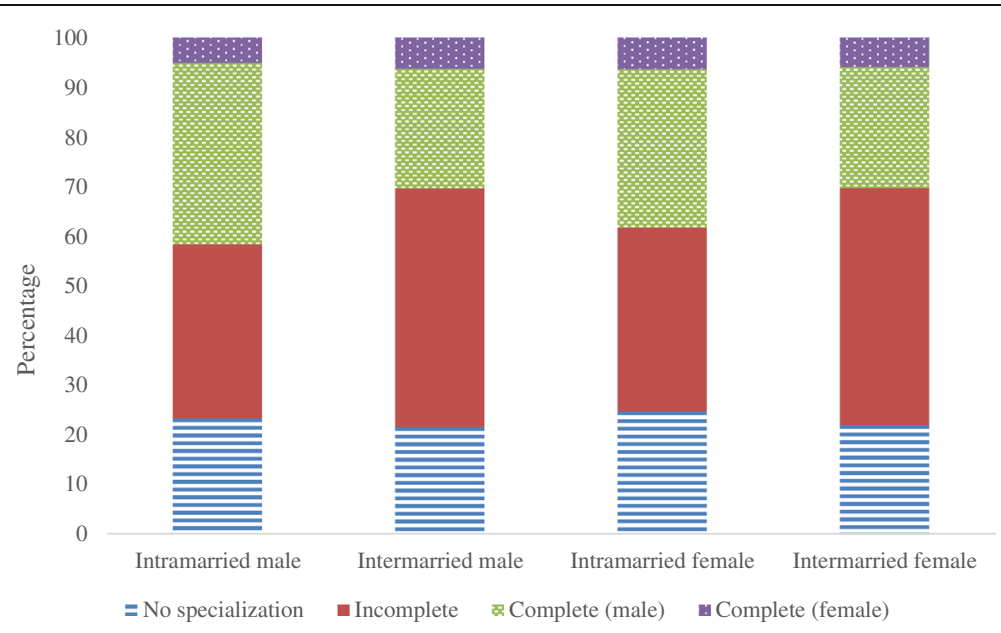

Fig. 1 Household specialization of immigrant households: by type of marriage and immigrant gender. Source: 2010 ACS

language proficiency and years of residence in the USA, weaken specialization for female immigrant households. ${ }^{18}$ Adding characteristics of the marriage does not significantly impact the results in columns 5 and 6 . The coefficients on these variables follow the usual signs. The presence of children and longer duration of marriage increase specialization in the household.

Columns 7 and 8 introduce metropolitan characteristics and birthplace controls. We continue to see lower specialization in intermarried male households $(-17 \%)$ and higher specialization in intermarried female households $(+6 \%)$. An increased availability of women vis-à-vis men in one's MSA is inversely related to women's labor force participation (Grossbard and Amuedo-Dorantes 2008) and increases household specialization. A larger own-country network reduces specialization in these households.

Specialization differences between intermarried and intra-married households depend on the sex of the immigrant spouse. The decreased gender-based division of labor in intermarried female households is a result of human capital endowments between spouses and is reversed when controls are introduced. Finally, coefficients on other variables that affect the costs and benefits of the marriage follow the predictions of the theory as discussed in Section 2.

\subsection{Alternative estimation strategy: instrumental variables}

The model in the previous section does not account for unobserved selection into intermarriage, and hence, the results may not establish a causal relationship between type of marriage and household specialization (endnote 6). In this section, we adopt an alternative estimation strategy and endogenize the marriage decision using a relative group size $\left(\mathrm{RGS}_{i, c, m, a}\right)$ instrumental variable (Meng and Gregory 2005; Basu 2015). People prefer mates within their own age, ethnic, and religious groups (Qian and Lichter 2001) vis-à-vis other groups. People who belong to a larger group also identify strongly with their ethnic group, increasing the chances of intra-marriage (Kalmijn and Van Tubergen 2010). 


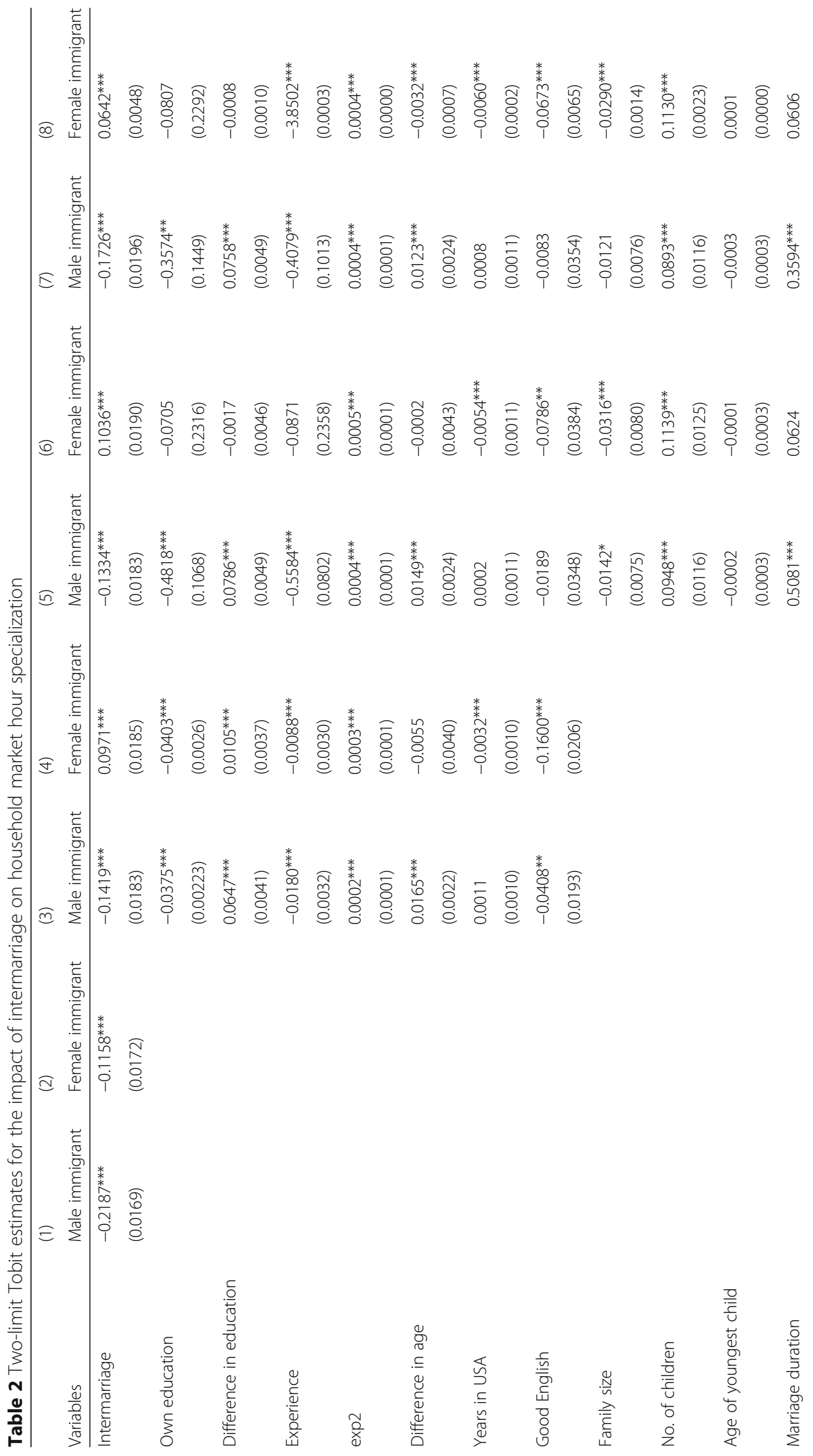




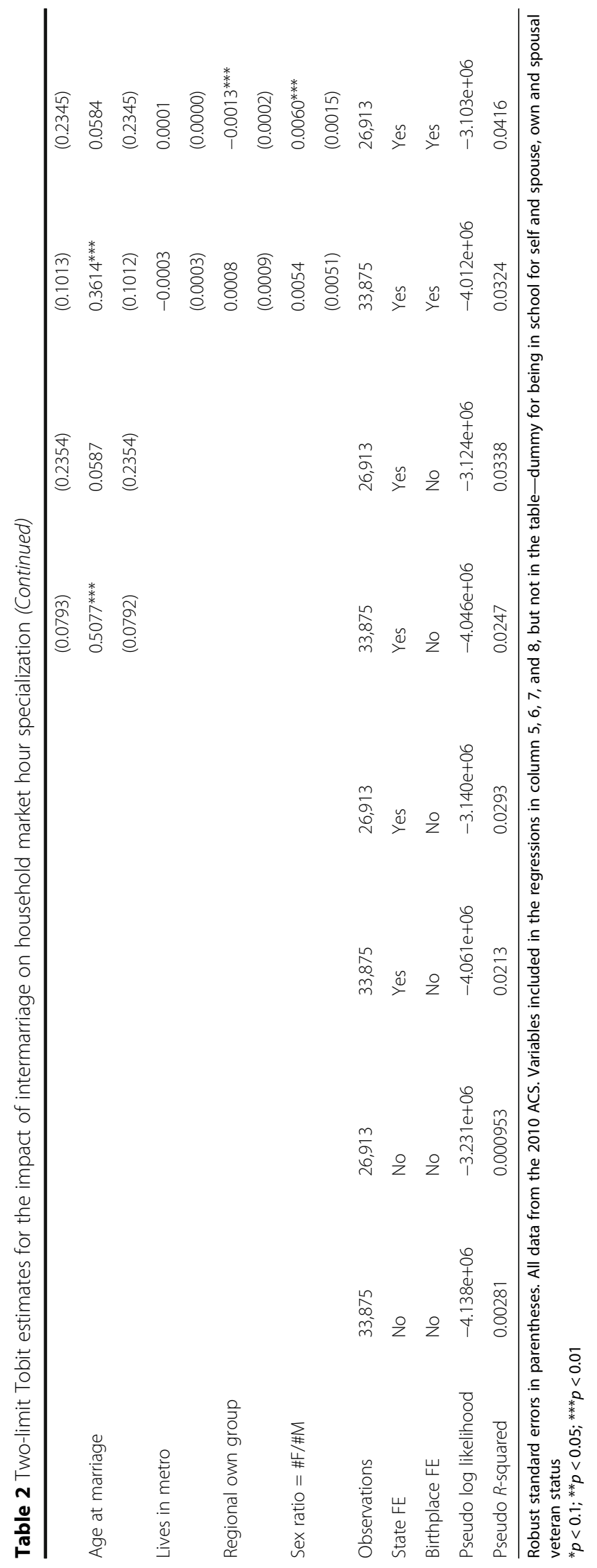


Availability of "similar" mates increases the probability of intra-marriage. $\mathrm{RGS}_{i, c, m, a}$ $=\left(\frac{\mathrm{UM}_{c, m, a}}{\mathrm{UM}_{\mathrm{USA}, m, a}}\right)$ where $\mathrm{UM}_{c, m, a}$ is the number of unmarried people of the opposite sex from the immigrant's country-of-birth $c$, age-group $a$, and metropolitan statistical area $m$. $\mathrm{UM}_{\mathrm{USA}, m, a}$ is similarly defined for unmarried individuals born in the USA.

Immigrants make residence, work, and marriage decisions based on local socioeconomic conditions. The orthogonality of the instrument to the outcome variable can be questioned. Furthermore, MSAs are often large geographic areas to count as meaningful marriage market locations-this can reduce the variation in the instrument. ${ }^{19}$ Finally, IV estimates are local average treatment effects. Household specialization decisions of immigrant sub-populations whose marriage decision depends on their communities' relative group size are estimated.

Table 3 presents the first- and second-stage results from the IV estimates. The values of the Kleibergen-Paap $X^{2}$ test and the $F$ test of excluded instruments are sufficiently high to reject the respective nulls of an under-identified model and an identified model that suffers from a weak correlation between the instrument and the endogenous variable. A $10 \%$ increase in the availability of unmarried mates from one's own country, age group, and MSA (relative to native mates) reduces the probability of intermarriage by $0.6 \%$ for women and $0.5 \%$ for men.

Owing to large standard errors, the coefficients on intermarriage are no longer significant in the second stage. ${ }^{20}$ Nevertheless, even upon altering the functional form of the estimation strategy, the direction of our results remains the same. Comparing the second-stage coefficients on the intermarriage variable of Table 3 to the two-limit Tobit estimates in columns 7 and 8 of Table 2, we see that the IV estimates point to higher specialization in intermarried households. The "traditional" nature of immigrants or natives who intermarry is often unobservable. For example, traditional immigrant women may marry traditional native men and such women may exchange their labor market ambitions for higher social status from marriage to a native.

Given the problems surrounding the IV estimates, we use it to further understand the correlation between intermarriage and household specialization and support our Tobit estimates. Our preferred specification is the two-limit Tobit regression, even though we may not fully account for unobservable selection into marriage and endogeneity.

\section{Explanations for the heterogeneous impact of intermarriage, by gender}

The household division of labor, and how spouses allocate labor supply to the market, differs between intermarried and intra-married immigrant households and by gender of the immigrant. This section examines potential mechanisms behind the differences.

\subsection{Role of education: own and spousal}

Own and relative spousal human capital affects specialization differentially by type of marriage and gender of the immigrant (Table 2). We further investigate the role of education which is an important determinant of labor market outcomes and matching between partners. We separate the sample first by own and then by spouse's education level and analyze household specialization responses for male and female immigrant 
Table 3 IV estimates for the impact of intermarriage on household market hours specialization

\begin{tabular}{|c|c|c|c|c|}
\hline \multirow[t]{2}{*}{ Variables } & \multicolumn{2}{|c|}{ Male immigrant } & \multicolumn{2}{|c|}{ Female immigrant } \\
\hline & First & Second & First & Second \\
\hline \multirow[t]{2}{*}{ Intermarriage } & & -0.0729 & & 0.0840 \\
\hline & & $(0.4131)$ & & $(0.4839)$ \\
\hline \multirow[t]{2}{*}{ Own education } & 0.2388 & -0.1990 & $-0.2857^{* * *}$ & $-0.4634^{* * *}$ \\
\hline & $(0.2785)$ & $(0.1354)$ & $(0.0886)$ & $(0.1066)$ \\
\hline \multirow[t]{2}{*}{ Difference in education } & $-0.0134^{* * *}$ & $0.0229^{* * *}$ & $-0.0141^{* * *}$ & 0.0035 \\
\hline & $(0.0009)$ & $(0.0058)$ & $(0.0011)$ & $(0.0072)$ \\
\hline \multirow[t]{2}{*}{ Experience } & 0.2230 & $-0.2698^{* *}$ & $-0.3209^{* * *}$ & $-0.3913^{* *}$ \\
\hline & $(0.2880)$ & $(0.1314)$ & $(0.0853)$ & $(0.1617)$ \\
\hline \multirow[t]{2}{*}{$\exp 2$} & 0.0000 & $0.0002^{* * *}$ & $-0.0000^{*}$ & $0.0002^{* * *}$ \\
\hline & $(0.0000)$ & $(0.0000)$ & $(0.0000)$ & $(0.0000)$ \\
\hline \multirow[t]{2}{*}{ Difference in age } & 0.0002 & $0.0058^{* * *}$ & $0.0060^{* * *}$ & -0.0010 \\
\hline & $(0.0007)$ & $(0.0009)$ & $(0.0014)$ & $(0.0033)$ \\
\hline \multirow[t]{2}{*}{ Years in USA } & $0.0127^{* * *}$ & 0.0004 & $0.0110^{* * *}$ & -0.0028 \\
\hline & $(0.0004)$ & $(0.0052)$ & $(0.0004)$ & $(0.0053)$ \\
\hline \multirow[t]{2}{*}{ Good English } & $0.1495^{* * *}$ & -0.0100 & $0.1660^{* * *}$ & -0.0752 \\
\hline & $(0.0062)$ & $(0.0628)$ & $(0.0067)$ & $(0.0813)$ \\
\hline \multirow[t]{2}{*}{ Family size } & $-0.0155^{* * *}$ & -0.0069 & $-0.0230^{* * *}$ & -0.0122 \\
\hline & $(0.0022)$ & $(0.0070)$ & $(0.0023)$ & $(0.0117)$ \\
\hline \multirow[t]{2}{*}{ No. of children } & $0.0134^{* * *}$ & $0.0377^{* * *}$ & $0.0128^{* * *}$ & $0.0475^{* * *}$ \\
\hline & $(0.0035)$ & $(0.0069)$ & $(0.0039)$ & $(0.0078)$ \\
\hline \multirow[t]{2}{*}{ Marriage duration } & -0.2361 & $0.2582^{*}$ & $0.3111^{* * *}$ & $0.3853^{* *}$ \\
\hline & $(0.2879)$ & $(0.1352)$ & $(0.0852)$ & $(0.1571)$ \\
\hline \multirow[t]{2}{*}{ Age at marriage } & -0.2347 & $0.2584^{*}$ & $0.3171^{* * *}$ & $0.3837^{* *}$ \\
\hline & $(0.2879)$ & $(0.1347)$ & $(0.0852)$ & $(0.1599)$ \\
\hline \multirow[t]{2}{*}{ Instrument: group size } & $-0.0511^{* * *}$ & & $-0.0600^{* *}$ & \\
\hline & $(0.0187)$ & & $(0.0243)$ & \\
\hline Observations & 30,893 & 30,893 & 24,345 & 24,345 \\
\hline$R$-squared & & 0.0463 & & 0.0620 \\
\hline Cragg-Donald $F$ test & 13.77 & 13.77 & 13.57 & 13.57 \\
\hline Kleinbergen-Paap rK LM $x^{2}$ & 9.911 & 9.911 & 11.23 & 11.23 \\
\hline
\end{tabular}

Standard errors clustered at the birthplace; MSA and age-group level shown in parentheses. All data from the 2010 ACS. Variables included in the regression, but not in the table-age of youngest child, dummy for being in school for self and spouse, own and spousal veteran status ${ }^{*} p<0.1 ;{ }^{* *} p<0.05 ;{ }^{* * *} p<0.01$

households. Table 4 presents these results. Panel A captures heterogeneous returns to intermarriage by own education level, conditional on spouse's education. The exercise is repeated by spousal education level, conditional on immigrant's education in panel $\mathrm{B}$. Four education levels are considered-high school dropout, high school graduate, college graduate, and post-college graduate. Other controls from Section 2.2 are included.

For immigrants with a post-college education, irrespective of gender, the level of specialization between intermarried and intra-married households is insignificant. For households with male immigrants, specialization, as a response to intermarriage, increases with the husband's level of education. At lower levels of male human capital, the division of labor is less gendered. The opposite is the case for intermarried women. 
Table 4 Effects of intermarriage on household specialization: by education level

\begin{tabular}{lllll}
\hline Variables & HS dropout & HS grad & College grad & Post college \\
\hline Panel A: own education category & & & & \\
Male intermarriage & $-0.3216^{* * *}$ & $-0.2232^{* * *}$ & $-0.1751^{* * *}$ & 0.0233 \\
Observations & $(0.0090)$ & $(0.0313)$ & $(0.0427)$ & $(0.0402)$ \\
Female intermarriage & 9707 & 11,299 & 5557 & 5487 \\
& 0.1320 & $0.0437^{* * *}$ & 0.0431 & 0.0383 \\
Observations & $(0.0803)$ & $(0.0079)$ & $(0.0338)$ & $(0.0358)$ \\
State FE & 6217 & 9524 & 5448 & 3644 \\
Birthplace FE & Yes & Yes & Yes & Yes \\
Panel B: spousal education category & Yes & & Yes & Yes \\
Male intermarriage & -0.1131 & $-0.2156^{* * *}$ & $-0.1561^{* * *}$ & -0.0617 \\
& $(0.0734)$ & $(0.0312)$ & $(0.0359)$ & $(0.0395)$ \\
Observations & 8454 & 11,749 & 6767 & 4562 \\
Female intermarriage & $0.1120^{* * *}$ & 0.0147 & $0.0786^{* *}$ & $0.0566^{* * *}$ \\
& $(0.0109)$ & $(0.0331)$ & $(0.0367)$ & $(0.0091)$ \\
Observations & 6628 & 9355 & 4922 & 4398 \\
State FE & Yes & Yes & Yes & Yes \\
Birthplace FE & Yes & Yes & Yes & Yes \\
\hline
\end{tabular}

Robust standard errors in parentheses. All data is from the 2010 ACS

${ }^{*} p<0.1 ;{ }^{* *} p<0.05 ;{ }^{* * *} p<0.01$

Household specialization decreases as the wife's education increases. This could possibly imply that women with more education supply labor market hours more similar to their husband.

Summing up, at lower levels of immigrant education, the native partner takes on a larger labor market role. Even if the native partner's education level is low, which we expect due to assortative mating, their "native status" accords more labor market opportunities. Connections with native networks, familiarity with native institutions, citizenship, and legal work status can compensate a native for their own and spouse's lower education attainments.

Less clear patterns emerge when the sample is divided along spousal education levels in panel B. The importance of own education, controlling for spousal levels, is underscored.

\subsection{Presence of "family investment motive"}

In this section, we look at the role of the family investment motive and how it varies by type of marriage (Becker and Benjamin, 1997; Eckstein and Weiss 2002). Immigrant wives may take on low-pay-high-hour work while their husbands are building human capital. As the immigrant husband gains human capital over their stay in the USA, both spouses move to better jobs. Presumably this "family investment" by wives is less necessary for intermarried families involving a native husband that are not usually creditconstrained. ${ }^{21}$ In the presence of these motives, we expect gender-based specialization of labor between intra-married immigrant female families to differ across the duration of the marriage. 
Figure 2 shows the difference in specialization for intermarried and intra-married families, conditional on all controls from Section 2.2, for different durations of marriage. $^{22}$ The figure does not provide conclusive evidence for the family investment hypothesis. ${ }^{23}$ Intermarried and intra-married female immigrant households at the beginning of the marriage, i.e., at 0-5 years, have insignificant differences in specialization (1\%). At 6-10 and 11-20 years of marriage, intermarried female households are significantly more specialized, but this continues even in the third and fourth decade of marriage.

On the other hand, specialization in intermarried male households continuously rises with duration of marriage. In the initial years, native wives might work more while the immigrant husband invests in human capital. Gender-based specialization occurs over the course of the marriage as the immigrant husband increases his market labor supply. This is supported by Table 4, where specialization is negligible across intermarried and intra-married males at the highest end of the education distribution, who presumably do not require assistance from their wives.

In general, except the fourth decade of marriage when the sample size of married households is small, intermarried male households are less specialized over the duration of a marriage. ${ }^{24}$ In the USA, labor force participation of wives is affected by husband's education and dynamically so (Gihleb and Lifshitz 2016). Native wives with more education than their husbands enter the labor force to compensate for their husband's lack of human capital-wives build experience and remain in the labor force even after husbands become primary breadwinners.

\subsection{Role of bargaining power}

Distribution of bargaining power can affect household specialization differentially between intermarried and intra-married couples. The source of this bargaining power, and as a result whether the wife or husband is favored, is theoretically ambiguous.

Bargaining power can stem from being legally married. Households that are less characterized by assortative mating are expected to last longer and are costly to dissolve,

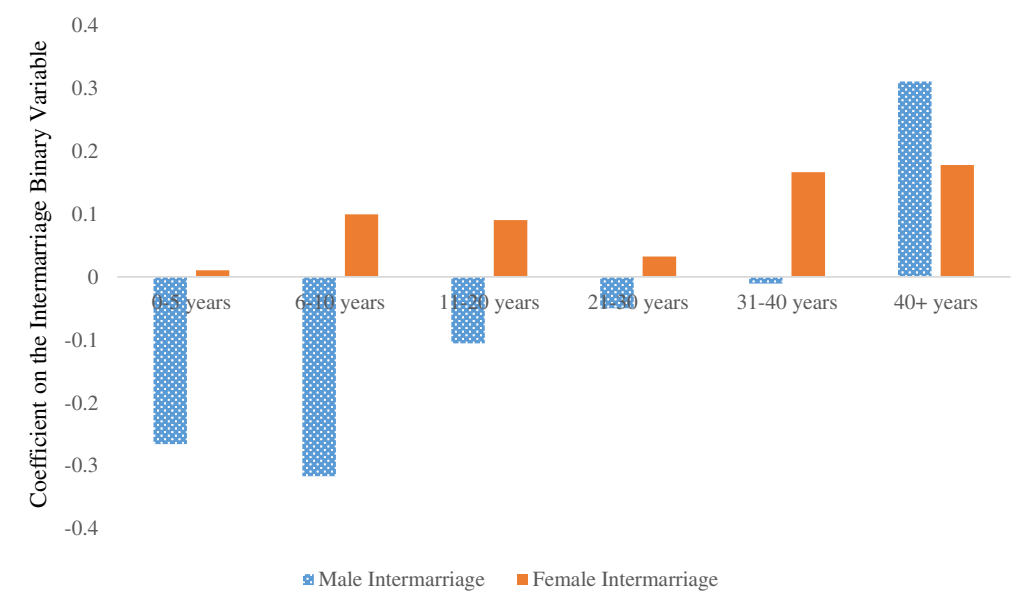

Fig. 2 Household specialization: by duration of marriage. Source: 2010 ACS. Bar heights show the difference in specialization between intermarried and intra-married households, conditional on all observables introduced in Section 2.2 
for example, marriages, which will choose to specialize compared to households that have a shorter duration, like cohabitations (Stratton 2005). Hence, bargaining power tends to be more equally divided between cohabiting partners and less likely along traditional gender lines compared to married partners. Thus, marriages in general will have more specialization.

The other source of bargaining power, in the context of this paper, stems from living with a native. Both in married and unmarried partnerships, the balance of bargaining power can tilt against the immigrant and lead to higher household specialization. ${ }^{25} \mathrm{Na}$ tives are familiar with the host-country institutions and norms. Immigrants may face discrimination.

Ideally, we would use household decision-making or distribution of wealth data to proxy for bargaining power, but we do not have this data. Instead, we estimate the model from Section 3.1 for cohabiting heterosexual couples, who have never been married and entered the USA younger than age 21 . We use this sample to compare the sources of bargaining power in living with a native-marriage over and above shared residence with a native.

Table 5 shows the two-limit Tobit estimates for the unmarried cohabiting sample. The raw estimates point to lower specialization in "inter-living" households compared to intra-living households, irrespective of gender (39\% for men and 34\% for women). Upon inclusion of controls for own and spousal human capital characteristics and family controls, the lower specialization seen for inter-immigrants reduces to a $14 \%$ difference for men and $2 \%$ for women. ${ }^{26}$ Addition of birthplace controls does not qualitatively change these results.

The results for inter-living and intermarried male households are similar-they are less specialized than their "intra-" counterparts. Inter- and intra-living female households have insignificant differences in household specialization. Marriage, however, increased gender-based specialization in intermarried female households. This is supported by previous research where natives choose to marry immigrant women from traditional societies for family-building purposes (Basu 2015).

\section{Robustness checks}

\subsection{Households with traditional gender roles}

Households generally follow the traditional male-breadwinner model-however, there are few families where only the wife works (Fig. 1) or works strictly more hours (endnote 17). In this section, we exclude households where women work strictly more than men. The remaining households constitute the "traditional" subsample. Results are presented in Table 6. Raw estimates and estimates including entire set of controls are presented.

The results for the "traditional" subsample are similar to the estimates for the entire sample. Columns 1 and 2 show that intermarriage is correlated with lower specialization compared to their intra-married counterparts for both genders. This finding reverses for female immigrants when human capital controls are included.

\subsection{Results: by immigrant's place of origin}

Rates of intermarriage among immigrants also differ by their place of origin. Immigrants from Europe have a higher rate of intermarriage compared to Asian or Hispanic 


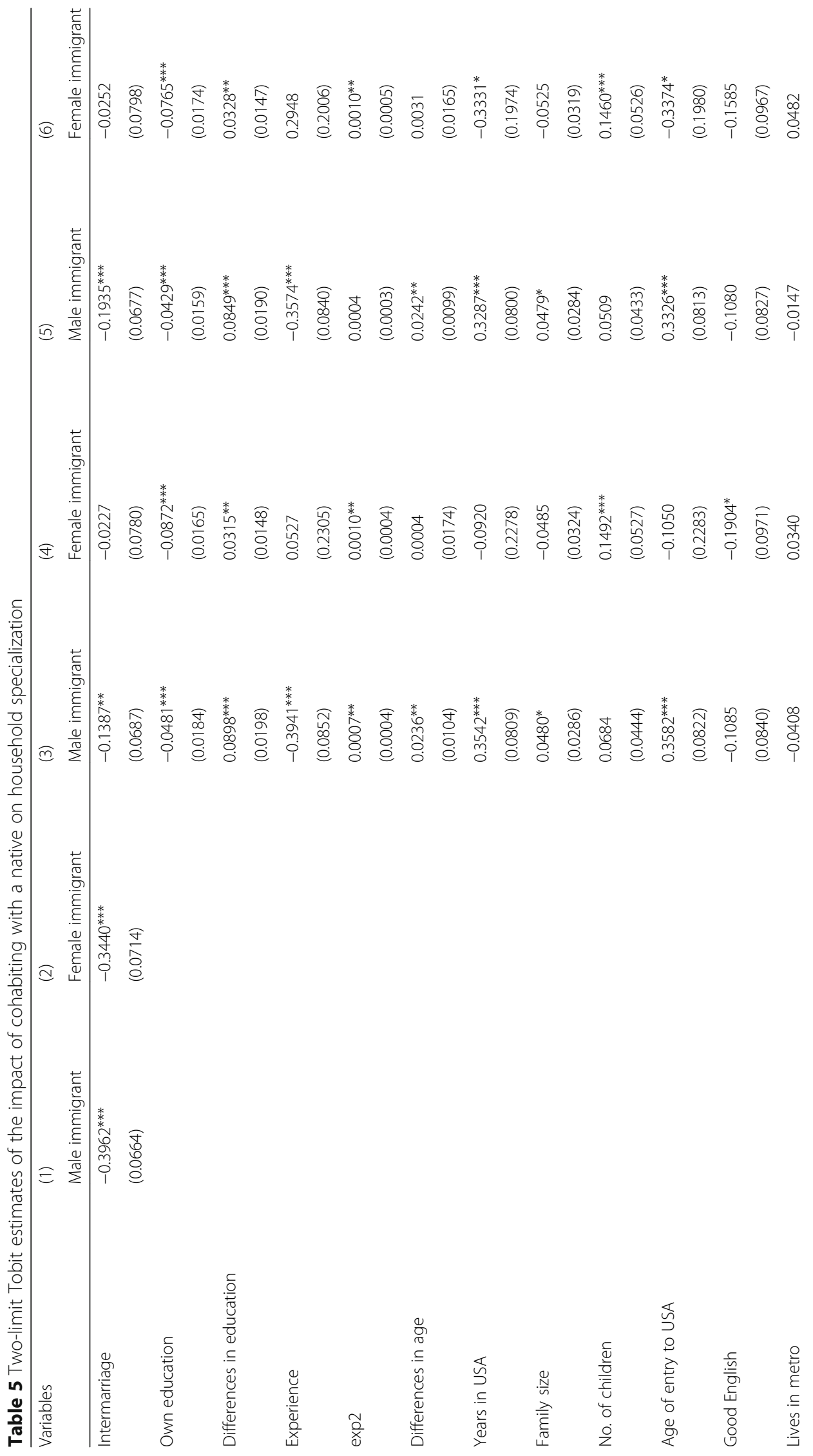




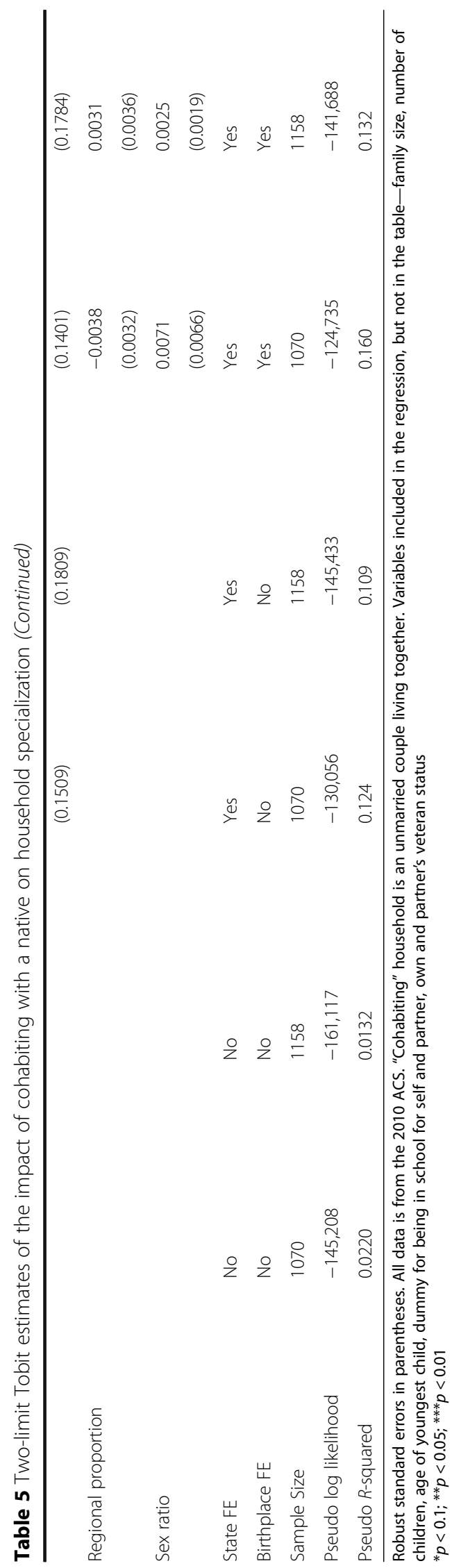


Table 6 Two-limit Tobit estimates for the impact of intermarriage on household specialization: subsample of households with "traditional" gender roles

\begin{tabular}{|c|c|c|c|c|}
\hline Variables & Male immigrant & Female immigrant & Male immigrant & Female immigrant \\
\hline \multirow[t]{2}{*}{ Intermarriage } & $-0.2772^{* * *}$ & $-0.1289^{* * *}$ & $-0.2268^{* * *}$ & $0.0961^{* * *}$ \\
\hline & $(0.0211)$ & $(0.0215)$ & $(0.0241)$ & $(0.0058)$ \\
\hline \multirow[t]{2}{*}{ Own education } & & & $-0.1267^{* *}$ & -0.0304 \\
\hline & & & $(0.0514)$ & $(0.0863)$ \\
\hline \multirow[t]{2}{*}{ Difference in education } & & & $0.0212^{* * *}$ & 0.0022 \\
\hline & & & $(0.0014)$ & $(0.0014)$ \\
\hline \multirow[t]{2}{*}{ Experience } & & & $-0.4986^{* *}$ & $-0.5759^{* * *}$ \\
\hline & & & $(0.2113)$ & $(0.0003)$ \\
\hline \multirow[t]{2}{*}{$\operatorname{exp2}$} & & & $0.0003^{* * *}$ & $0.0004^{* * *}$ \\
\hline & & & $(0.0001)$ & $(0.0000)$ \\
\hline \multirow[t]{2}{*}{ Difference in age } & & & $0.0160^{* * *}$ & $0.0037^{* * *}$ \\
\hline & & & $(0.0030)$ & $(0.0009)$ \\
\hline \multirow[t]{2}{*}{ Years in USA } & & & 0.0013 & $-0.0076^{* * *}$ \\
\hline & & & $(0.0014)$ & $(0.0003)$ \\
\hline \multirow[t]{2}{*}{ Good English } & & & $-0.0531^{* *}$ & $-0.2234^{* * *}$ \\
\hline & & & $(0.0242)$ & $(0.0067)$ \\
\hline \multirow[t]{2}{*}{ Family size } & & & $-0.0164^{*}$ & $-0.0404^{* * *}$ \\
\hline & & & $(0.0094)$ & $(0.0017)$ \\
\hline \multirow[t]{2}{*}{ No. of children } & & & $0.1093^{* * *}$ & $0.1446^{* * *}$ \\
\hline & & & $(0.0141)$ & $(0.0028)$ \\
\hline \multirow[t]{2}{*}{ Marriage duration } & & & $0.4699^{* *}$ & 0.287 \\
\hline & & & $(0.2105)$ & $(0.3374)$ \\
\hline \multirow[t]{2}{*}{ Age at marriage } & & & $0.4718^{* *}$ & 0.282 \\
\hline & & & $(0.2105)$ & $(0.333)$ \\
\hline \multirow[t]{2}{*}{ Lives in metro } & & & -0.0034 & $-0.0555^{* * *}$ \\
\hline & & & $(0.0427)$ & $(0.0079)$ \\
\hline \multirow[t]{2}{*}{ Regional own group } & & & 0.0006 & $-0.0026^{* * *}$ \\
\hline & & & $(0.0011)$ & $(0.0003)$ \\
\hline \multirow[t]{2}{*}{ Sex ratio } & & & 0.0071 & 0.0025 \\
\hline & & & $(0.0066)$ & $(0.0019)$ \\
\hline State FE & No & No & Yes & Yes \\
\hline Birthplace FE & No & No & Yes & Yes \\
\hline Observations & 33,875 & 26,913 & 33,875 & 26,913 \\
\hline Pseudo log likelihood & $-4.138 \mathrm{e}+06$ & $-3.231 e+06$ & $-4.012 \mathrm{e}+06$ & $-3.103 e+06$ \\
\hline Pseudo $R$-squared & 0.00281 & 0.000953 & 0.0324 & 0.0416 \\
\hline
\end{tabular}

Robust standard errors in parentheses. All data is from the 2010 ACS. A traditional household is one where the husband supplies at least as many market hours as the wife ${ }^{*} p<0.1 ;{ }^{* *} p<0.05 ;{ }^{* * *} p<0.01$

immigrants (Basu 2015). Within these birthplace categories, there are differences in rates of intermarriage for men and women. Given the longer history of European immigration to the USA, it is possible that cultural similarities affect both the probability of intermarriage and the level of household specialization for these groups differently from other immigrant groups. 
Table 7 shows results for three broad origin groups-Latin America, Asia, and Europe. Controls from Section 2.2 are carried over. Most immigrants in our sample originate from Latin America. We continue to see that the male sample is characterized by lower specialization as a result of intermarriage and women have a higher level of specialization. However, the specialization difference is small and insignificant between intermarried and intra-married European immigrants, for both genders.

\subsection{Results: by immigrant's age of entry}

Age of entry of the immigrant is not included as a control in the estimations due to concerns of collinearity. Bleakley and Chin (2010) show that age of arrival affects social assimilation of immigrants-primarily their language proficiency and spousal choice$\mathrm{s}$-and these effects are heterogeneous by gender of the immigrant. If age of entry affects spouse choice, and age of entry is known to impact labor market outcomes, the impact of intermarriage on household specialization can differ by gender and age of entry of immigrants.

Table 8 divides the sample into four categories-pre-teen entrants, teen entrants, those arriving in their 20s, and those who arrived after age 30. For all these ages of entry, intermarried male households exhibit a lower degree of specialization compared to intra-married families. For female households, those arriving as teenagers exhibit a lower degree of specialization if intermarried. Spouse choices of women arriving in this psycho-sexual development period can be affected by unobservable factors that our estimations cannot account for.

\section{Conclusions}

Intermarriage between immigrants and natives has mixed outcomes on labor market outcomes of the foreign-born population in the USA. Previous research shows that there are little significant gains for immigrant males, and penalties for women, upon controlling for observable and unobservable selection. This paper seeks to study the impact of intermarriage on household specialization. Marriage itself being a joint decision between two individuals is likely to influence how spouses decide to allocate their labor market hours. This analysis could then help to better understand the overall impact of intermarriage on immigrant socioeconomic assimilation. Furthermore, spouse selectivity differs across natives by gender, and intermarriage affects the traditional gender-based division of labor, translating to differences in specialization in intermarried male and female households.

Table 7 Effects of intermarriage on household specialization: by immigrant place of origin

\begin{tabular}{llll}
\hline & Latin America & Asia & Europe \\
\hline Male intermarriage & $-0.263^{* * *}$ & $-0.125^{* * *}$ & -0.0160 \\
& $(0.0281)$ & $(0.0402)$ & $(0.0495)$ \\
Observations & 17,431 & 10,767 & 3451 \\
Female intermarriage & $0.0656^{* *}$ & $0.048^{* * *}$ & 0.0103 \\
Observations & $(0.0323)$ & $(0.013)$ & $(0.008)$ \\
State FE & 13,594 & 8435 & 3071 \\
\hline
\end{tabular}


Table 8 Effects of intermarriage on household specialization: by immigrant age of entry

\begin{tabular}{lllll}
\hline Variables & Pre-teen entrant & Teenage entrant & Entered in 20s & Entered after age 30 \\
\hline Male intermarriage & $-0.1495^{* *}$ & $-0.1419^{* * *}$ & $-0.2035^{* * *}$ & $-0.1384^{* * *}$ \\
& $(0.0639)$ & $(0.0396)$ & $(0.0299)$ & $(0.0069)$ \\
Observations & 1747 & 4313 & 14,705 & 13,110 \\
Female intermarriage & $0.1277^{* * *}$ & $-0.0418^{* * *}$ & $0.0513^{* * *}$ & $0.1677^{* * *}$ \\
& $(0.0140)$ & $(0.0093)$ & $(0.0072)$ & $(0.008)$ \\
Observations & 1960 & 4534 & 11,410 & 9009 \\
State FE & Yes & Yes & Yes & Yes \\
Birthplace FE & Yes & Yes & Yes & Yes \\
\hline
\end{tabular}

Robust standard errors in parentheses. All data is from the 2010 ACS

${ }^{*} p<0.1 ;{ }^{* *} p<0.05 ;{ }^{* * *} p<0.01$

The raw estimates show that gender-based specialization is lower in intermarried households, for men and women. However, the inclusion of own and relative spousal human capital reverses this finding for female intermarried immigrants. Their households exhibit a higher level of market specialization.

The most important explanation for the differences in household specialization, conditional on marriage, is the immigrant's own level of education. Immigrants at the highest end of the education distribution have no significant difference in specialization by marriage type. At low levels of immigrant education, lack of human capital of the immigrant spouse are traded off for the native partner's work hours. This manifests as increased (decreased) gender-based specialization in intermarried female (male) households. We do not find evidence of a family investment motive among intra-married families that shows these couples coordinate labor market efforts.

Finally, we investigate the role of bargaining power and its source. "Inter-living" households where couples merely cohabit are characterized by lower specialization, visà-vis their "intra-" counterparts. Hence, the act of marriage to a native increases the cost of dissolving a partnership and increases gender-based specialization for intermarried female immigrants.

A corollary to time spent on market work is hours spent on household work. For future work, time use surveys can present a more complete picture regarding the differences in division of labor (Bonke et al. 2008) across intermarried and intra-married families and by immigrant gender.

Marriage to natives is an important road to legal residence and citizenship in the USA. If marriage affects household, and consequently individual decisions to supply market labor, the role of intermarriage is important when considering the effectiveness of immigration policy.

\section{Endnotes}

${ }^{1}$ Throughout this paper, the terms immigrant and foreign-born are used interchangeably to refer to individuals born outside the 50 US states and District of Columbia. Anyone born in the USA is a native, irrespective of their parents' birthplace. Intermarriages between natives and immigrants can also be considered "cross-country" marriages.

${ }^{2}$ Cross-racial marriages among US-born descendants of immigrants are increasing (Pew Research Center 2012). However, these marriages are not the focus of this paper, since both partners are natives. 
${ }^{3}$ Furtado and Theodoropoulos (2010) find that intermarriage affects employment opportunities of immigrant men in the USA positively. They attribute this to access to native networks.

${ }^{4}$ The paper uses the term "immigrant male households" to refer to households of married foreign-born men who either have an immigrant wife (intra-married) or native wife (intermarried). "Immigrant female households" are similarly defined.

${ }^{5} \mathrm{Chi}$ (2015) suggests that intermarriage wage premiums for immigrant males differ by initial levels of human capital, particularly their education and English proficiency.

${ }^{6}$ Alternatively, the selection hypothesis states that intermarried immigrants are positively selected into the labor and marriage market. Traits like motivation and attachment to the host country cannot be observed, but they increase intermarriage and participation in the host country labor market. Household distribution of labor can itself determine intermarriage.

${ }^{7}$ Hence, intra-married families, as they stay in the host country, may move from high levels of household specialization (which often does not follow traditional gender lines) to more equal division of labor among spouses. Depending on the duration of stay, comparable intermarried female households may exhibit more specialization than intra-married households.

${ }^{8}$ Grossbard et al. (2014) show that among inter-racial marriages in the USA, the minority-race partner, irrespective of gender, increases their home hours of labor compared to their intra-married counterparts. The majority-race partner, presumably, has higher outside options and more bargaining power.

${ }^{9}$ Gender differences in labor force participation of intermarried immigrants are explained by observable selection and birthplace fixed effects.

${ }^{10}$ Given our estimations are conducted separately for male and female immigrants, it may help the reader to think of the household index from the point of view of a particular spouse.

${ }^{11}$ Given our definition of native and immigrant, a second generation individual, who is born in the USA, is classified as a native, and their marriage to another native is a native intra-marriage and not the focus of this paper. On the other hand, some intraracial marriages can be intermarriages. For example, Hispanic immigrants who marry Hispanic natives are in an intermarriage. Immigrants from different foreign countries who marry are intra-married.

${ }^{12}$ These relative variables are constructed as difference in the numerical values of the respective variables for $i$ and $j$ multiplied by indicator variables for $i$ being more educated/older.

${ }^{13}$ For immigrants not living in identifiable MSAs, the state-level sex ratio and immigrant concentration ratios are used.

${ }^{14}$ Married individuals living separately are excluded, since relative spousal human capital are important determinants of intermarriage and household specialization.

${ }^{15} \mathrm{We}$ exclude households where both partners state they work zero weekly market hours.

${ }^{16}$ If an immigrant self-reports only speaking English or speaking very well, he or she has "good English."

${ }^{17}$ In households with incomplete specialization, $15 \%$ of intra-married and $17 \%$ of intermarried families report the wife working more hours than the husband. 
${ }^{18}$ Exclusion of language or duration variables did not change the qualitative results. The main channel via which specialization in intermarried female households is affected is own and relative human capital.

${ }^{19}$ Previous research studying the causal impact of intermarriage on labor market outcomes of immigrants frequently uses the regional and birthplace-specific sex ratio as an instrument. This is a control in our estimations. It clearly affects household specialization of married immigrant women-see Table 2. This instrument would not be a valid instrument.

${ }^{20}$ Standard errors are clustered by MSA, birthplace, and age group of the immigrant.

${ }^{21}$ This motive may exist for native women married to immigrant husbands-the wife is the primary breadwinner in the early period of the marriage while the immigrant husband acquires host country capital. Given intermarried native women have high human capital, it is not clear they would accept low-pay work, though they may work more hours.

${ }^{22}$ Note that this is a cross-section of marriages, not a panel. Continuing marriages, even at their early stages, could be different from marriages that dissolve sooner.

${ }^{23}$ Blau et al. (2003) also do not find evidence of the family investment motive for immigrant families in the USA.

${ }^{24}$ We use categories of "marriage duration" rather than "residence in the USA" since we expect household specialization to be coordinated within the marriage. An immigrant could live in the USA without being married.

${ }^{25}$ For the sake of convenience, we will refer to "unmarried cohabitation with a native" as "inter-living."

${ }^{26}$ The controls that significantly affect specialization, like the married sample, are own and spousal human capital. Family controls, like number of children, while important in determining household specialization, do not significantly change the differences in household specialization by type of cohabitation.

\section{Acknowledgements}

I am grateful to participants at the Stockman Conference at the University of Rochester for comments. I would also like to thank an anonymous referee and the editor for useful remarks. All remaining errors are my own. Responsible editor: Denis Fougère

\section{Competing interests}

The IZA Journal of Development and Migration is committed to the IZA Guiding Principles of Research Integrity. The author declares that he has/she has observed these principles.

Received: 26 September 2016 Accepted: 11 April 2017

Published online: 14 July 2017

\section{References}

Adserà A, Ferrer A. Immigrants and demography: marriage, divorce, and fertility. IZA discussion paper series no. 7982. 2014. Available at http://ftp.iza.org/dp7982.pdf. Accessed 3 Oct 2016.

Baker M, Benjamin D. The role of the family in immigrants' labor market activity: an evaluation of alternative explanations. Am Econ Rev. 1997;87(4):705-27.

Basu S. Intermarriage and the labor market outcomes of Asian women. Econ Inq. 2015;53(4):1718-34.

Basu S. Intermarriage and the labor-force participation of immigrants: differences by gender. 2016. Available at SSRN: http://ssrn.com/abstract=2828835, Accessed 1 Sept 2016.

Becker G. A treatise on the family. Cambridge, MA: Harvard University Press; 1981.

Becker G. Human capital, effort, and the sexual division of labor. J Labor Econ. 1985;3(1):33-58. Part 2: Trends in Women's Work, Education, and Family Building.

Blau F, Kahn L, Moriarty J, Souza A. The role of the family in immigrants' labor-market activity: an evaluation of alternative explanations: comment. Am Econ Rev. 2003;93(1):429-47.

Bleakley $\mathrm{H}$, Chin A. Age at arrival, English proficiency and social assimilation among immigrants. Am Econ J Appl Econ. 2010;2(1):165-92. 
Bonke J, Deding M, Lausten M, Stratton L. Intra-household specialization in housework in the United States and Denmark. Soc Sci Q. 2008;89(4):1023-43.

Chi M. Does intermarriage promote economic assimilation among immigrants in the United States? Int J Manpow. 2015;36(7):1034-57.

Chiswick B, Houseworth C. Ethnic intermarriage among immigrants: human capital and assortative mating. Rev Econ Househ. 2011;9(2):149-80.

Eckstein Z, Weiss Y. The integration of immigrants from the Former Soviet Union in the Israeli labor market. In: The Israeli Economy 1985-1998: from government intervention to market economics essays in memory of Prof. Michael Bruno. Cambridge MA: MIT Press; 2002. p. 349-78.

Espiritu Y. Gender and labor in Asian immigrant families. Am Behav Sci. 1999;42(4):628-47.

Furtado D. Human capital and interethnic marriage decisions. Econ Inq. 2012;50(1):82-93.

Furtado D, Theodoropoulos N. Why does intermarriage increase immigrant employment? The role of networks. The B.E. $J$ Econ Anal Policy 10(1): Article 101 1-33. 2010.

Gevrek E, Gevrek D, Gupta S. Culture, intermarriage, and immigrant women's labor supply. Int Migr. 2013;51 (6):146-67. Gihleb R, Lifshitz O. Dynamic effects of educational assortative mating on labor supply. IZA discussion paper no. 9958. 2016. Available at http://ftp.iza.org/dp9958.pdf, Accessed 15 Dec 2016.

Gordon M. Assimilation in American life: the role of race, religion and national origins. New York: Oxford University Press; 1994.

Grossbard S, Amuedo-Dorantes C. Cohort-level sex ratio effects on women's labor force participation. Rev Econ Househ. 2008;6(3):309.

Grossbard S, Gimenez-Nadal Jl, Molina J. Racial intermarriage and household production. Rev Behav Econ. 2014;1(4):295-347.

Grossbard-Shechtman S. On the economics of marriage: a theory of marriage labor, and divorce. Boulder: Westview Press; 1993.

Grossbard-Shechtman S, Fu X. Women's labor-force participation and status exchange in intermarriage: a model and evidence for Hawaii. J Bioecon. 2002;4(3):241-68

Jasso G, Massey D, Rosenzweig M, Smith J. Assortative mating among married new legal immigrants to the United States: evidence from the new immigrant survey pilot. Int Migr Rev. 2000;34(2):443-59.

Kalmijn M, van Tubergen F. A comparative perspective on intermarriage: explaining differences in marriage choices among national origin groups in the United States. Demography. 2010:47(2):459-79.

Kantarevic J. Interethnic marriages and economic assimilation of immigrants. IZA discussion paper series no. 1142. 2004. Available at http://ftp.iza.org/dp1142.pdf, Accessed 1 Sept 2016.

Lichter D, Carmalt J, Qian Z. Immigration and intermarriage among Hispanics: crossing racial and generational boundaries. Sociol Forum. 2011;26(2):241-64.

Lundberg S, Pollak R. Bargaining and distribution in marriage. J Econ Perspect. 1996;10(4):139-58.

Lundberg S, Pollak R. The American family and family economics. J Econ Perspect. 2007;21(2):3-26.

Meng X, Gregory R. Intermarriage and the economic assimilation of immigrants. J Labor Econ. 2005;23(1):135-76.

Meng X, Meurs D. Intermarriage, language, and economic assimilation process: a case study of France. Int J Manpow. 2006;30(2):127-44.

Milewski N, Kulu H. Mixed marriages in Germany: a high risk of divorce for immigrant-native couples. Eur J Popul. 2014; 30(1):89-113.

Nottmeyer O. Relative labor supply in intermarriage. IZA J Migr. 2014;3(1):1-27. doi:10.1186/2193-9039-3-3.

Nottmeyer O. Intermarriage and the economic success of immigrants. IZA world of labor: 160. 2015. doi: 10.15185/izawol.160

Pew Research Center. The rise of intermarriage: rates, characteristics vary by race and gender. 2012. Available at http:// www.pewsocialtrends.org/files/2012/02/SDT-Intermarriage-II.pdf. Accessed 1 Sept 2016.

Qian Z, Lichter D. Measuring marital assimilation: intermarriage among natives and immigrants. Soc Sci Res. 2001;30(2):289-312.

Ruggles S, Alexander J, Genadek K, Goeken R, Schroeder M, Sobek M. Integrated public use microdata series: version 5. 0 [machine-readable database]. Minneapolis: University of Minnesota; 2013.

Stratton L. Specialization in household activities within cohabiting versus married households. 2005. Mimeo, Available at http://paa2005.princeton.edu/papers/50047. Accessed 1 Sept 2016.

\section{Submit your manuscript to a SpringerOpen ${ }^{\circ}$ journal and benefit from:}

- Convenient online submission

- Rigorous peer review

- Immediate publication on acceptance

- Open access: articles freely available online

- High visibility within the field

- Retaining the copyright to your article

Submit your next manuscript at $\boldsymbol{\nabla}$ springeropen.com 